JURNAL ILMIAH ELEKTRONIKA DAN KOMPUTER, Vol.13, No.1, Juli 2020, pp. 116 - 120

p-ISSN : $1907-0012$ (print)

e-ISSN : 2714-5417 (online)

http://journal.stekom.ac.id/index.php/elkom

- page 116

\title{
SISTEM PENDUKUNG KEPUTUSAN PENILAIAN KINERJA KARYAWAN DENGAN METODE ANALYTIC HIERARCHY PROCESS (AHP)
}

\author{
Zaenal Mustofa ${ }^{1}$, Arsito Ari Kuncoro ${ }^{2}$, Rizky Aji Prasetyo ${ }^{3}$ \\ ${ }^{1}$ Sistem Komputer - Universitas STEKOM, Zaenalmustofa@stekom.ac.id \\ ${ }^{2}$ Sistem Komputer - Universitas STEKOM, arsito@stekom.ac.id \\ ${ }^{2}$ Teknik Informatika - Universitas STEKOM, risky_aji123@gmail.com \\ J1. Majapahit 605, Semarang, telp/fax : 024-6717201-02
}

\begin{tabular}{l}
\hline ARTICLE INFO \\
\hline Article history: \\
Received 24 Juli 2020 \\
Received in revised form Juli 2020 \\
Accepted Juli 2020 \\
Available online Juli 2020
\end{tabular}

\begin{abstract}
Decision Support System in Employee Performance Appraisal is a web-based system used to support decision making for outsourcing employee contract extensions. This study aims to provide a decision support information system in employee performance appraisal so that employee performance appraisals and employee contract extension decisions can be carried out systematically. Currently, employee performance appraisals and decision making for employee contract extensions are still done manually using spreadsheets. The method used in the design of decision support systems in the web-based employee performance appraisal is the method of calculating the assessment using the AHP (Analytic Hierarchy Process) method and the prototype system development method. The design of this system provides convenience to the personnel staff and the head of personnel in assessing and making decisions for employees who are about to expire their contract. The system can also be a means for personnel staff in accessing reports on employee data whose performance has been assessed by the division head and makes it easier for personnel staff to make decisions on employee contract extensions. With the system, employees will be more motivated to do their job better.
\end{abstract}

Keywords: Decision Support System, Assessment, Performance, Employees

\section{1) Pendahuluan}

PT. Gazia Multi Usaha yang merupakan perusahaan penyalur tenaga kerja kontrak di PT. Kayu Lapis Indonesia. PT.Gazia Multi Usaha memiliki jumlah tenaga kerja yang terbilang banyak dan cenderung meningkat. Hal ini dibuktikan dengan peningkatan jumlah karyawan dari tahun 2015-2017, dengan jumlah karyawan pada tahun 2015 sebanyak 855 orang, 2016 sebanyak 938 orang, dan pada akhir bulan april 2017 sebanyak 1.023 orang. Jumlah tenaga kerja yang banyak tersebut ditempatkan di berbagai departemen atau divisi dalam perusahaan. Misalnya pada divisi marketing jumlah karyawan 50 orang, pada divisi internal audit jumlah karyawan 15 orang, pada divisi akuntansi jumlah karyawan 10 orang, dll.

Hal ini menyebabkan penilain kinerja terhadap karyawan tidak sesuai dengan keadaan dilapangan. Saat ini yang terjadi dilapangan penilaian terhadap karyawan masih subjektif karena penilaian banyak yang

Received mei 22, 2020; Revised mei 30, 2020; Accepted juli 9, 2020 
berdasarkan kesenangan pimpinan terhadap karyawan tersebut, sehingga hasil penilaian tidak sesuai dengan kriteria penilaian yang sudah ditetapkan oleh perusahaan.

Pembuatan sistem pendukung keputusan (SPK) dapat melalui metode Analytic Hierarchy Process (AHP). AHP adalah suatu metode penilaian dengan cara melakukan perbandingan berpasangan dari masing - masing kriteria penilaian. Metode AHP dipilih karena dalam penelitian ini metode AHP adalah yang paling tepat untuk melakukan penilaian dengan terdapat beberapa faktor yang akan menjadi hasil evaluasi.

\section{2) Perumusan Masalah}

1. Belum adanya sistem yang dapat diterpakan dalam penilaian kinerja karyawan masih subjektif atu penilaian banyak yang berdasarkan kesenangan pimpinan terhadap karyawan tersebut sehingga menyebabkan penilain kinerja terhadap karyawan tidak sesuai dengan keadaan dilapangan

\section{3) Landasan Teori}

a. Sistem Informasi

Menurut Sutarman (2012:13) sistem informasi adalah sistem yang didefinisikan dengan mengumpulkan, memproses, menyimpan, menganalisis, menyebarkan informasi untuk tujuan tertentu. Menurut Laudon, Kenneth C dan Jane P. Laudon (2012:16) sistem informasi adalah komponen-komponen yang saling berkaitan yang bekerja bersama-sama untuk mengumpulkan, mengolah, menyimpan, dan menampilkan informasi untuk mendukung pengambilan keputusan, koordinasi, pengaturan, analisa, dan visualisasi pada sebuah organisasi.

\section{b. Sistem Pendukung Keputusan}

Menurut Turban (2005:137) sistem pendukung keputusan adalah sistem berbasis komputer yang terdiri dari tiga komponen yang saling berinteraksi, sistem bahasa (mekanisme untuk memberikan komunikasi antara pengguna dan komponen sistem pendukung keputusan lain), sistem pengetahuan (respositori pengetahuan domain masalah yang ada pada sistem pendukung keputusan atau sebagai data atau sebagai prosedur), dan sistem pemrosesan masalah (hubungan antara dua komponen lainnya, terdiri dari satu atau lebih kapabilitas manipulasi masalah umum yang diperlukan untuk pengambilan keputusan).

c. Penilaian Kinerja

Menurut Hasibuan, Malayu (2012:118) mengartikan bahwa penilaian kinerja adalah menilai rasio dengan standar kualitas maupun kuantitas yang dihasilkan setiap karyawan.

d. AHP (Analitycal Hierarchy Process)

Menurut Kazibudzki dan Tadeusz (2013:Vol 8, Nomor 8) mendefinisikan Analytic Hierarchy Process (AHP) adalah pengambilan keputusan multikriteria dengan dukungan metodologi yang telah diakui dan diterima sebagai prioritas yang secara teori dapat memberikan jawaban yang berbeda dalam masalah pengambilan keputusan serta memberikan peringkat pada alternatif solusinya.

Model AHP yang memakai persepsi decision maker sebagai inputnya maka ketidakkonsistenan mungkin terjadi karena manusia memiliki keterbatasan dalam menyatakan persepsinya secara konsisten terutama kalau harus membandingkan banyak kriteria. Berdasarkan kondisi ini maka decision maker dapat menyatakan persepsinya dengan bebas tanpa harus berfikir apakah persepsinya tersebut akan konsisten nantinya atau tidak. Penentuan konsistensi dari matriks itu sendiri didasarkan atas eigen value maksimum, yang diperoleh dengan rumus seperti tampak pada gambar 2.1

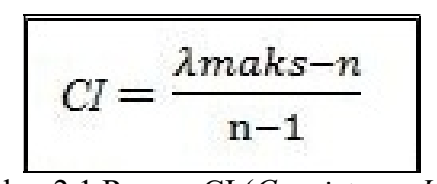

Gambar 2.1 Rumus CI (Consistency Index) 
Jika nilai CI sama dengan nol, maka matriks pairwise comparison tersebut konsisten. Batas ketidak konsistenan yang telah di tetapkan dengan menggunakan consistency ratio (CR), yaitu perbandingan indeks konsistensi dengan nilai random indeks (RI). Consistency ratio dapat dirumuskan pada rumus gambar 2.2.

$$
\begin{gathered}
C R=\frac{C I}{R I} \\
\text { Gambar 2.2 Rumus CR (Consistency Ratio) }
\end{gathered}
$$

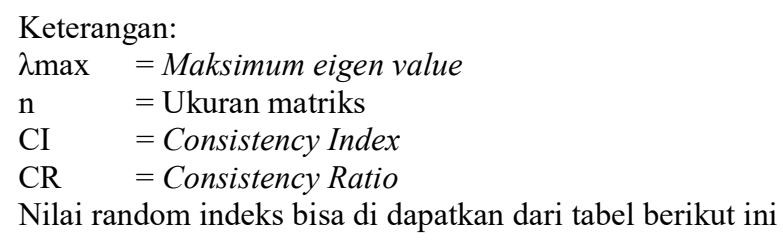

Tabel 2.1 Nilai Random Indeks (RI)

\begin{tabular}{|l|c|c|c|c|c|c|c|c|c|c|}
\hline \hline Nilai & 1 & 2 & 3 & 4 & 5 & 6 & 7 & 8 & 9 & 10 \\
\hline $\begin{array}{l}\text { Random } \\
\text { Indeks }\end{array}$ & 0.00 & 0.00 & 0.58 & 0.90 & 1.12 & 1.24 & 1.32 & 1.41 & 1.45 & 1.48 \\
\hline
\end{tabular}

Jika matriks perbandingan berpasangan (pair -wise comparison) dengan nilai CR lebih kecil dari 0,100 maka ketidak konsistenan pendapat pengambil keputusan masih dapat diterima dan jika tidak maka penilaian perlu diulang.

\section{e. Unified Modeling Language (UML)}

Unified Modeling Language adalah sebuah "bahasa" yang telah menjadi standar dalam industri untuk visualisasi, meranc ang dan mendokumentasikan sistem piranti lunak. UML menawarkan sebuah standar untuk merancang model suatu sistem. Dengan menggunakan UML kita dapat membuat model untuk semua jenis aplikasi piranti lunak dimana aplikasi tersebut dapat berjalan pada piranti keras, sistem operasi dan jaringan apapun serta ditulis dalam bahasa pemrograman apapun (Yuni Sugiarti, $2013: 34$ ).

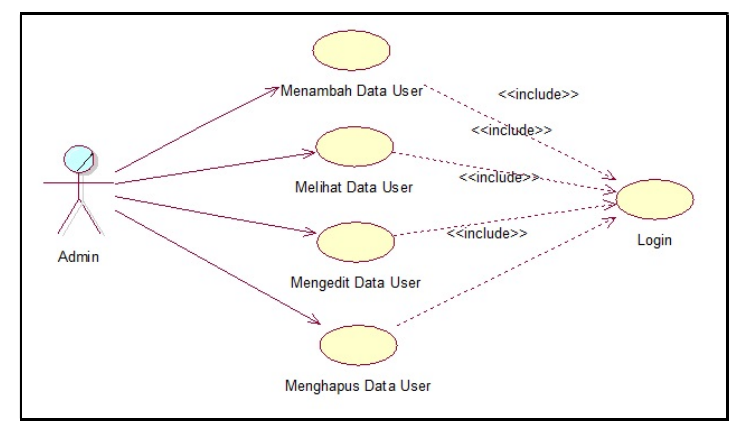

Gambar 2.3 Diagram Sistem Use Case Admin

JURNAL ILMIAH ELEKTRONIKA DAN KOMPUTER Vol. 13, No. 1, Juli 2020 : 116 - 120 


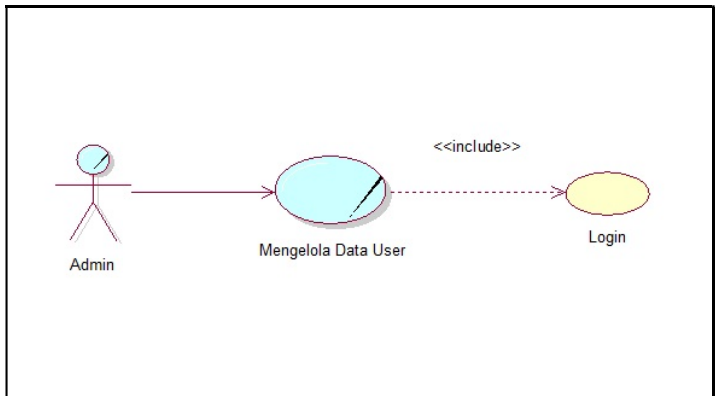

Gambar 2.4 Diagram Bisnis Use Case Admin

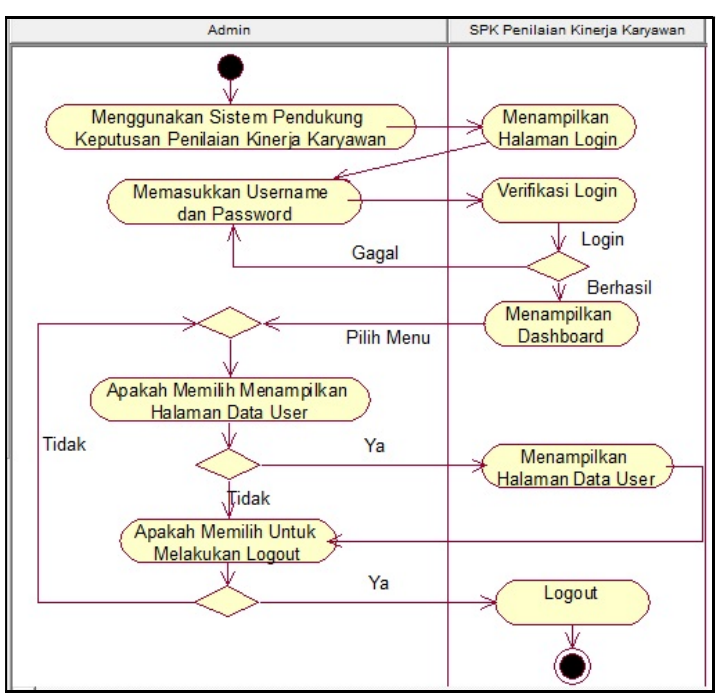

Tabel 2.5 Diagram Activity Admin

4) Hasil

a. Tampilan Dashboard Admin

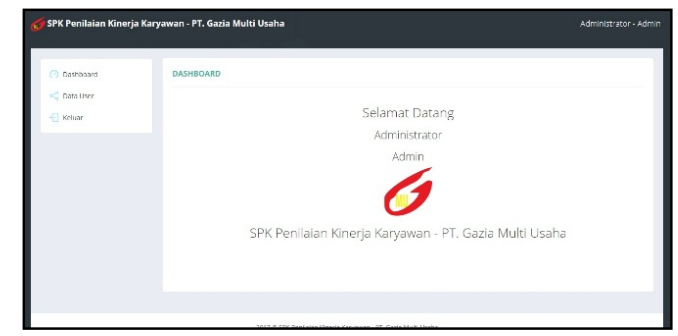

Gambar 2.6 Halaman Dashboard Admin

b. Menu Input Data Karyawan

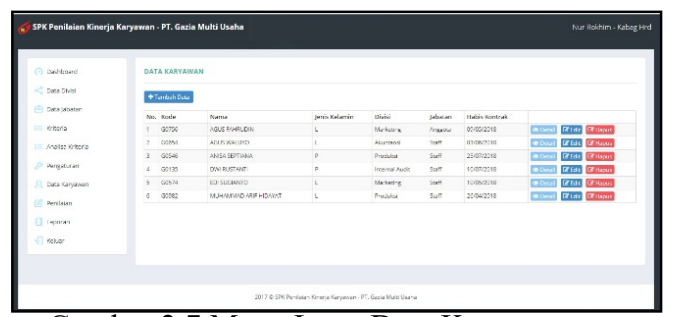

Gambar 2.7 Menu Input Data Karyawan 
c. Menu Input Data Penilaian

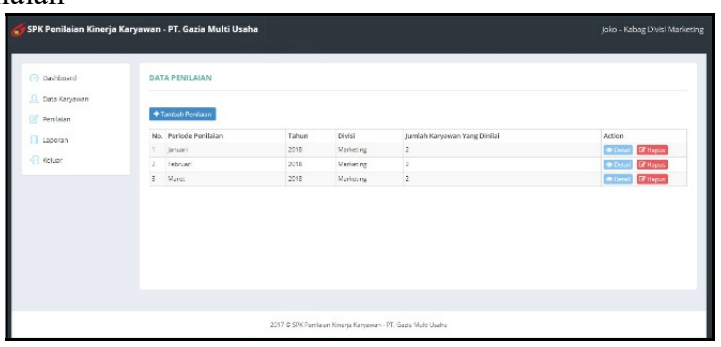

Gambar 2.8 Menu Input Data Penilaian

d. Menu Hasil Penilaian

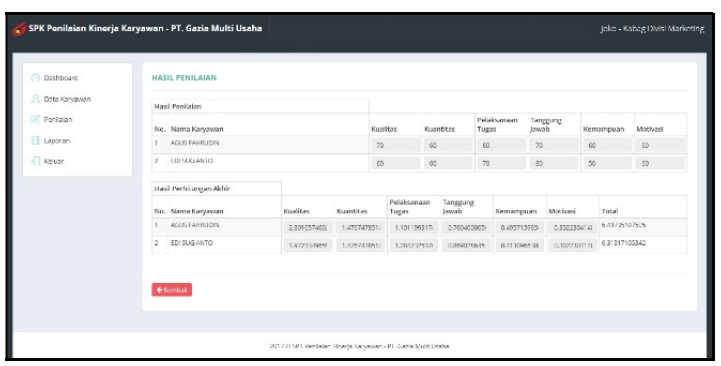

Gambar 2.9 Menu Hasil Penilaian

\section{5) Kesimpulan}

Hasil dari perancangan sistem pendukung keputusan penilaian kinerja karyawan dengan menggunakan metode AHP (Analytic Hierarchy Process) berbasis web studi kasus pada PT. Gazia Multi Usaha Kendal dapat diambil kesimpulan sebagai berikut:

1. Sistem pendukung keputusan dalam penilaian kinerja karyawan berbasis web studi kasus pada PT. Gazia Multi Usaha dapat mempermudah pekerjaan staff personalia dalam pendataan karyawan.

2. Sistem pendukung keputusan dalam penilaian kinerja karyawan berbasis web studi kasus pada PT. Gazia Multi Usaha dapat menjadi sarana untuk membuat laporan penilaian kinerja karyawan pada tiap bulan.

3. Sistem pendukung keputusan dalam penilaian kinerja karyawan berbasis web studi kasus pada PT. Gazia Multi Usaha dapat mempermudah pekerjaan Kepala divisi dalam melakukan penilaian kinerja karyawan yang berada pada divisi tersebut. 